\section{Effect of GA on Inflorescence in. Uniconazole-treated Chrysanthemums}

\author{
E. Jay Holcomb, Loren D. Tukey, and Mark A. Rose \\ Department of Horticulture, The Pennsylvania State University, \\ University Park PA 16802
}

Additional index words. $\mathrm{G}_{3}$, growth retardant, triazole, Dendrathema $\times$ grandiflorum
Growth retardants are applied to most potted chrysanthemums produced commercially. The reduced peduncle length gives the inflorescence on the plant an undesirable "clubby" shape. Holcomb and Homa (1980) reduced the clubby appearance of chrysanthemums by delayed pinching. Foliar sprays of gibberellic acid $\left(\mathrm{GA}_{3}\right)$ reduced clubby growth of spray chrysanthemums (Lert and Nishimoto, 1959). Foliar sprays of $\mathrm{GA}_{3}$ at $20 \mathrm{mg} \cdot \mathrm{liter}^{-1}$ applied on the $21 \mathrm{st}$ or 28 th short day produced elongated peduncles without causing flower abnormalities (Kofranek and Cockshull, 1985). Holcomb and Tukey (unpublished data) found potted chrysanthemums mot-treated with uniconazole had inflorescences that were clubby.

The objective of this experiment was to determine the optimal timing of foliar sprays of $\mathrm{GA}_{3}$ on potted chrysanthemums, previously root-treated with uniconazole, to correct for a clubby inflorescence.

Cuttings of Dendranthema $\times$ grandifloone cutting per pot, in $900-\mathrm{cm}^{3}$ pots during mid-January and pinched 2 weeks later. The plants were grown with night-break lighting to keep them vegetative. Short days (SD) were started the day after the plants were pinched. On 10 Feb. 1988 (week O), the cuttings were large enough $(=10 \mathrm{~cm})$ for treatment. The growth retardant (E)-1-(pchlorophenyl)-4,4 -dimethyl-2-(1,2,4 -triazol 1-yl)-1 penten-3-ol (uniconazole) was applied to the roots. at $0.1 \mathrm{mg}$ a.i./plant in 10 $\mathrm{ml}$ of water as a trunk soil-line pour (TSLP) (Tukey, 1986). Plants then were sprayed at weekly intervals with $20 \mathrm{mg} \mathrm{G} \mathrm{A} /$ liter $(\approx 4$ ml/plant). Treatments -(see Table 1) were replicated 10 times using a completely randomized design. Date of flowering was determined when the first inflorescence on a plant was fully open. The number of days to flower was determined as the difference between the planting and flowering dates. Data were tested by analysis of variance and mean separation by Duncan's multiple range test at $P=0.05$. Data on length of peduncle as a percentage of total height were transformed

Received for publication 12 Oct. 1989. Contribution no. 155, Dept. of Horticulture, The Pennsylvania State Univ. Paper no. 8300 in the Journal Series of the Pennsylvania Agricultural Experiwas defrayed in part by the payment of page charges. Under postal regulations, this paper therefore must be hereby marked advertisement solely to indicate this fact. rum (Ramat.) Kitamura 'Echo' were planted, ment Station. The cost of publishing this paper by square-root transformation before analysis.

$\mathrm{GA}_{3}$ applied as a foliar spray increased final plant height, while uniconazole reduced it (Table 1). $\mathrm{GA}_{3}$ applied at week 1, 2, or 3 increased the height of all uniconazole-treated plants, while $\mathrm{GA}_{3}$ applied at week 4 or 5 had little effect on plant height, probably because most of the peduncle elongation had already occurred.

Foliar $\mathrm{GA}_{3}$ caused elongation of suppressed terminal peduncles on uniconazoletreated plants when applied at certain times (Table 1). When $\mathrm{GA}_{3}$ was applied 1 week after uniconazole, it had no significant effect on peduncle length. The peduncles on plants treated with $\mathrm{GA}_{3} 2$ and 3 weeks after uniconazole were significantly longer than those treated with $\mathrm{GA}_{3}$ after 4 weeks. By weeks 4 and 5, the plants were mature; therefore, the terminal peduncle was not greatly affected by $\mathrm{GA}_{3}$. $\mathrm{GA}_{3}$ applied 3 weeks after uniconazole resulted in the most elongation of the peduncle and the most open flower spray (Fig. $1)$.

The percentage of the total height contribplants was 10\% (Table 1); in untreated plants, it was almost twice as much. For plants treated with $\mathrm{GA}_{3}$, the proportion increased up to week 3 . The effect of $\mathrm{GA}_{3}$ application at 3 weeks was similar to that found by Kofranek and Cockshull (1985) on cut chrysanthemums.

Application of $\mathrm{GA}_{3}$ at 3 weeks after uniconazole was applied caused the peduncle to elongate and created a marketable flowering potted chrysanthemum of desirable proportion rather than a clubby one.

\section{Literature Cited}

Holcomb, E.J. and S. Homa. 1980. Effects of delayed pinching on chrysanthemums. Florists' Rev. 166(4315):24-25.

Kofranek, A.M. and K.E. Cockshull. 1985. Improving the spray formation of pompon cultivars with gibberellic acid and intercalated long days. Acts Hort. 167:117-124.

Lert, P.J. and Y. Nishimoto. 1959. Gibberellins on chrysanthemum. Calif. Agr. April, 1959. p.

Tukey, L.D. 1986. Plant growth regulator absorption through roots. Acts Hort. 179:199-206. uted by the peduncle on uniconazole-treated

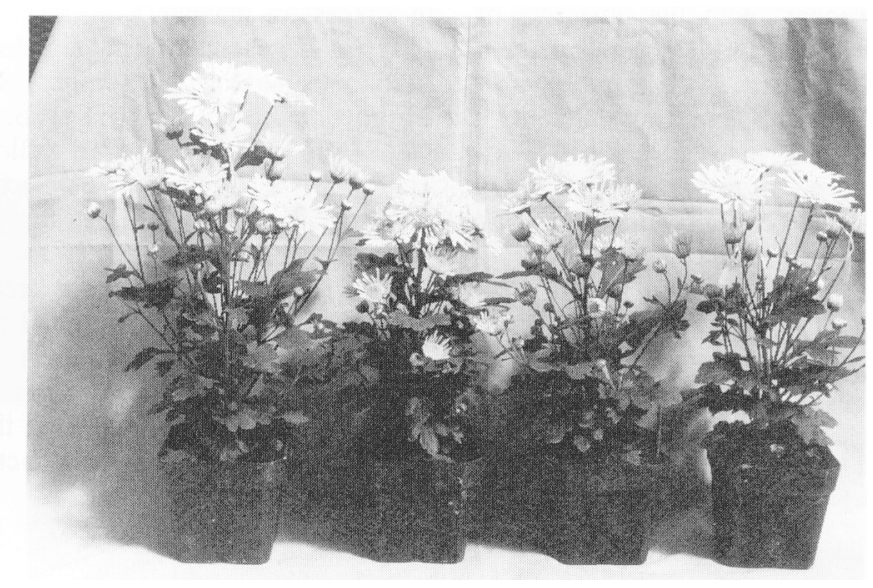

Fig. 1. Plants root-treated with uniconazole $\left(0.1 \mathrm{mg}\right.$ a.i./pot) followed by a $\mathrm{GA}_{3}$ spray $\left(20 \mathrm{mg} \cdot\right.$ liter $\left.^{-1}\right)$. (left to right) Untreated, $\mathrm{GA}_{3} 1,2$, and 3 weeks after uniconazole application.

Table 1. Uniconazole and $\mathrm{GA}_{3}$ effects on 'Bright Golden Anne' chrysanthemum. ${ }^{2}$

\begin{tabular}{ccccc}
\hline \hline \multicolumn{2}{c}{ Treatment } & & & \multicolumn{2}{c}{ Peduncle } \\
\cline { 1 - 2 } $\begin{array}{c}\text { Uniconazole } \\
\begin{array}{c}\text { applied to } \\
\text { roots }\end{array}\end{array}$ & $\begin{array}{c}\text { Foliar } \\
\mathrm{GA}_{3}{ }^{\mathrm{x}} \\
\text { (week no.) }\end{array}$ & $\begin{array}{c}\text { Plant ht } \\
(\mathrm{cm})\end{array}$ & $\begin{array}{c}\text { Length } \\
(\mathrm{cm})\end{array}$ & $\begin{array}{c}\text { Length as } \\
\text { percent total ht }\end{array}$ \\
\hline- & None & $27.5 \mathrm{e}$ & $5.0 \mathrm{~b}$ & $18 \mathrm{~b}$ \\
- & 0 & $32.2 \mathrm{f}$ & $8.0 \mathrm{c}$ & $25 \mathrm{c}$ \\
+ & None & $12.4 \mathrm{a}$ & $1.2 \mathrm{a}$ & $10 \mathrm{a}$ \\
+ & 1 & $21.3 \mathrm{c}$ & $2.2 \mathrm{a}$ & $10 \mathrm{a}$ \\
+ & 2 & $25.6 \mathrm{~d}$ & $4.6 \mathrm{~b}$ & $18 \mathrm{~b}$ \\
+ & 3 & $27.1 \mathrm{de}$ & $8.8 \mathrm{c}$ & $33 \mathrm{~d}$ \\
+ & 4 & $12.5 \mathrm{a}$ & $1.4 \mathrm{a}$ & $12 \mathrm{a}$ \\
+ & 5 & $17.5 \mathrm{~b}$ & $4.1 \mathrm{~b}$ & $23 \mathrm{c}$ \\
\hline
\end{tabular}

${ }^{2}$ Means based on 10 replications. Mean separation within columns by Duncan's multiple range test, $P$ $>0.05$.

'All applications (+) at week 0, Feb. 1988, $0.1 \mathrm{mg}$ a.i./pot.

${ }^{x} \mathrm{G} \mathrm{A}_{3}$ at $20 \mathrm{mg} \cdot 1$ iter $^{-1}$. 